\title{
Improved diagnostic test for Clostridium difficile: clinical and infection control implications
}

\author{
J Wilson *, E Brannigan, A Jepson, C Johnstone, S Hassall, A Holmes \\ From International Conference on Prevention \& Infection Control (ICPIC 2011) \\ Geneva, Switzerland. 29 June - 2 July 2011
}

\section{Introduction / objectives}

Clostridium difficile reporting is mandatory in England, numbers have increased since the mid-1990s with over 25000 reported per year. At Imperial College Healthcare it was observed that isolation of $C$. difficile from stool did not always reflect clinical disease; particularly when testing was changedto detection of glutamate dehydrogenase (GDH) and the $t c d B$ gene by PCR. Testing for $C$. difficile in liquid stools was not restricted. All positive patients were therefore reviewed to determine if they had C. difficile associated disease (CDAD).

\section{Methods}

A patient was considered to have CDAD if they had at least 3 episodes of diarrhoea in 24 hours, the stool was positive for C. difficile by PCR, diarrhoea was not attributable to another cause and symptoms consistent with pseudomembranous colitis. A standardised clinical review was undertaken to determine if new cases of $C$. difficile met the case definition. Data were captured prospectively on an electronic surveillance system (ICNet).

\section{Results}

250 patients admitted between June 2010 and January 2011 were test positive; of these, 166 (66\%) were classified as hospital-acquired. Clinical review found 67 (40\%) did not have CDAD: 29 (27\%) did not have diarrhoea; in 80 (73\%), diarrhoea was attributable to another cause, most commonly underlying bowel disease (38 cases). Severe disease occurred in 16\%; there were 7 deaths associated with CDAD.

\section{Conclusion}

This analysis indicates that improved laboratory tests for toxin-producing $C$. difficile do not correlate well with CDAD. Whilst this may be an advantage in terms of prompt initiation of infection control measures, reporting based on positive tests does not represent the true burden of disease and the laboratory method used diagnosis may have a significant impact on rates.

\section{Disclosure of interest}

None declared.

Published: 29 June 2011

doi:10.1186/1753-6561-5-S6-P182

Cite this article as: Wilson et al:: Improved diagnostic test for

Clostridium difficile: clinical and infection control implications. BMC

Proceedings 2011 5(Suppl 6):P182.
Submit your next manuscript to BioMed Central and take full advantage of:

- Convenient online submission

- Thorough peer review

- No space constraints or color figure charges

- Immediate publication on acceptance

- Inclusion in PubMed, CAS, Scopus and Google Scholar

- Research which is freely available for redistribution

\section{Biomed Central}

\section{Biomed Central}

C 2011 Wilson et al; licensee BioMed Central Ltd. This is an open access article distributed under the terms of the Creative Commons Attribution License (http://creativecommons.org/licenses/by/2.0), which permits unrestricted use, distribution, and reproduction in any medium, provided the original work is properly cited. 